Agnieszka Budnik

Powiatowy Zespół Kształcenia Specjalnego w Wejherowie

\title{
Prawa osób z niepełnosprawnością intelektualną w świetle europejskiego i polskiego ustawodawstwa ${ }^{1}$
}

Artykuł 32 Konstytucji Rzeczypospolitej Polskiej z dnia 2 kwietnia 1997 r. (Dz. U. z 1997 r. Nr 78, poz. 483, ze zm.) stanowi: „Wszyscy są wobec prawa równi. Wszyscy mają prawo do równego traktowania przez władze publiczne”. Grupom osób z niepełnosprawnością intelektualną lub zaburzeniami psychicznymi, które składają się na podmioty zainteresowań niniejszego artykułu, dedykowane są w Polsce niektóre artykuły kodeksów karnego, cywilnego, rodzinnego i opiekuńczego, a także ustawa o ochronie zdrowia psychicznego oraz ustawa o rehabilitacji zawodowej i społecznej oraz zatrudnieniu osób niepełnosprawnych. W ustawodawstwie europejskim są to między innymi: deklaracja praw osób upośledzonych umysłowo, deklaracja praw osób niepełnosprawnych, Karta Praw Osób Niepełnosprawnych czy Europejska Karta Społeczna. Jak można się domyślić, ich głównymi celami są: podniesienie jakości życia osób z różnymi niepełnosprawnościami oraz zapewnienie im bezpieczeństwa, środków do życia (renty, emerytury) oraz opieki i leczenia (domy pomocy społecznej, szpitale psychiatryczne).

Z wstępnych wyników Narodowego Spisu Powszechnego z 2011 roku w zakresie populacji osób niepełnosprawnych wynika, że liczba osób, które zadeklarowały ograniczenie zdolności do wykonywania zwykłych czynności podstawowych dla swojego wieku i/lub posiadały ważne orzeczenie kwalifikujące je do zaliczenia do zbiorowości osób niepełnosprawnych, wynosiła 4697 500, co stanowiło 12,2\% ludności kraju. Co ciekawe, w związku z dobrowolnym charakterem pytań dotyczących niepełnosprawności blisko 1,5 mln respondentów odmówiło udzielenia odpowiedzi. Można się domyślać, że wśród tej grupy osób także mogły znajdować się osoby niepełnosprawne (Wstępne wyniki z Narodowego Spisu Powszechnego... 2011).

Reasumując, grupy osób, których prawa są przedmiotem zainteresowania badawczego niniejszego artykułu, stanowią spory odsetek ludności kraju, dlatego tak ważne wydaje się podjęcie owego tematu. Celem publikacji jest analiza oraz

\footnotetext{
${ }^{1}$ Stan prawny: 26 lipca 2017 roku.
} 
omówienie wyżej wspomnianych artykułów i ustaw oraz prawodawstwa europejskiego, które bezpośrednio dotyczą osób z niepełnosprawnością oraz osób z zaburzeniami psychicznymi.

\section{Miejsce osób z niepełnosprawnością intelektualną w Unii Europejskiej - prawo antydyskryminacyjne}

Koniec XIX wieku i pierwsza połowa XX wieku to niechlubny czas w kartach historii dla rozwoju człowieka i cywilizacji. Rozwój pseudonauki - eugeniki, dwie wojny światowe, rewolucje i konflikty na całym świecie upodliły istotę człowieczeństwa, dzięki wymyślnym sposobom torturowania i mordowania ludzi. Po zakończeniu drugiej wojny światowej Organizacja Narodów Zjednoczonych uchwaliła Kartę Narodów Zjednoczonych, w której wezwała narody do poszanowania praw człowieka, szczególnie akcentując prawo do wolności, bez względu na płeć, język, rasę i wyznanie (Andrzejuk 2004: 41). Dokument ten, ratyfikowany przez wszystkie państwa, które odniosły straty w czasie wojny, ma istotne, symboliczne znaczenie, jednak brak w nim jakiejkolwiek wzmianki o osobach z niepełnosprawnością. Beata Cytowska twierdzi, że można ten fakt interpretować na dwa sposoby: „albo uznano te podmioty za mało znaczącą populację lub/i potraktowano je jak każdego innego człowieka, nie identyfikując czy nie naznaczając w ten sposób tej grupy społecznej" (Cytowska 2012: 134).

Zgromadzenie Ogólne Organizacji Narodów Zjednoczonych podjęło kolejny krok 10 grudnia 1948 roku, którym było opracowanie Powszechnej deklaracji praw człowieka. Znajduje się w nim pierwsze postanowienie antydyskryminacyjne: „Wszyscy ludzie rodzą się wolni i równi w swej godności i w swych prawach są oni obdarzeni rozumem i sumieniem i powinni postępować wobec innych w duchu braterstwa" (Sokołowski 2004: 12). Akt ten nakazuje niwelować różnice koloru skóry, rasy, płci, języka, religii, poglądów politycznych, narodowości, pochodzenia społecznego, majątku czy urodzenia (Piechowiak 1999: 89).

W latach pięćdziesiątych, sześćdziesiątych i siedemdziesiątych XX wieku Zgromadzenie Ogólne Organizacji Narodów Zjednoczonych ogłosiło kolejne akty mające na celu przeciwdziałanie dyskryminacji: konwencję dotyczącą dyskryminacji w zakresie zatrudnienia i wykonywania zawodu, przyjętą przez Międzynarodową Organizację Pracy w 1958 roku; konwencję w sprawie zwalczania dyskryminacji w dziedzinie oświaty, zatwierdzoną w 1960 roku przez Organizację Narodów Zjednoczonych dla Wychowania, Nauki i Kultury; konwencję w sprawie dyskryminacji rasowej z 1966 roku; konwencję w sprawie dyskryminacji kobiet z 1979 roku. Polska podpisała się pod każdym z wyżej wymienionych dokumentów (Cytowska 2012: 135). Sytuację osób niepełnosprawnych intelektualnie oraz innych niepełnosprawnych dostrzeżono dopiero w latach siedemdziesiątych XX wieku. Bernadeta Szczupał stwierdziła, że stało się to możliwe dzięki przejściu od modelu 
medycznego w pojmowaniu niepełnosprawności do modelu społecznego, głównie w państwach Europy Zachodniej (Szczupał 2009: 80). W 1971 roku przyjęto Deklarację praw osób upośledzonych umysłowo, natomiast w 1975 roku - Deklarację praw osób niepełnosprawnych. Deklaracja praw osób upośledzonych umysłowo określa prawa tych osób do: odpowiadającej potrzebom opieki lekarskiej i usprawniania fizycznego oraz do nauki, szkolenia, rehabilitacji i poradnictwa w takim zakresie, aby umożliwić maksymalny rozwój posiadanych uzdolnień i potencjalnych możliwości; zabezpieczenia środków utrzymania i godziwego poziomu życia; wykonywania pracy zarobkowej bądź innego pożytecznego zajęcia przy najpełniejszym wykorzystaniu ich uzdolnień; życia razem $\mathrm{z}$ własną rodziną względnie $\mathrm{z}$ rodziną zastępczą i uczestnictwa $\mathrm{w}$ różnych formach życia społecznego, a jeśli konieczne jest umieszczenie w zakładzie opiekuńczym, to warunki życia i otoczenie w tym zakładzie powinny być zbliżone do warunków normalnego życia; korzystania z pomocy opiekunów o odpowiednich kwalifikacjach; ochrony przed wyzyskiem, nadużyciami i poniżającym traktowaniem; normalnego postępowania sądowego z pełnym uwzględnieniem ich stopnia odpowiedzialności (Deklaracja praw osób upośledzonych umysłowo przyjęta przez Zgromadzenie Ogólne Organizacji Narodów Zjednoczonych uchwałą 2856 (XXVI) w dniu 9 grudnia 1975 roku). Obie wyżej wspomniane deklaracje podkreślają, że osoby z niepełnosprawnością mają takie same prawa jak inne istoty ludzkie w tym samym wieku, niezależnie od stopnia czy rodzaju niepełnosprawności i należy je chronić przed wszystkimi formami wykorzystania i traktowania, które mają charakter dyskryminacyjny i poniżający.

W latach 1983-1992 ogłoszono dekadę Osób Niepełnosprawnych. W tym okresie na organizacje i rządy nałożono obowiązek wprowadzenia w życie Światowego programu działania na rzecz osób niepełnosprawnych zatwierdzonego przez ONZ w 1982 roku. Program ten był efektem obchodów Międzynarodowego Roku Niepełnosprawnych, który przypadał na rok 1981. Pod koniec lat osiemdziesiątych ONZ ogłosiło dzień 3 grudnia Międzynarodowym Dniem Osób Niepełnosprawnych, mając na celu uświadamianie społeczeństw w kwestii niepełnosprawności oraz mobilizowanie do działań wspierających tę grupę społeczną oraz ich aktywne uczestnictwo (Cytowska 2012: 136). Dopiero w Konwencji o prawach dziecka przyjętej przez Zgromadzenie Ogólne Narodów Zjednoczonych dnia 20 listopada 1989 roku (Dz. U. z 1991 r. Nr 120, poz. 526) (dalej: konwencja o prawach dziecka) po raz pierwszy zwrócono uwagę na potrzebę chronienia dzieci z niepełnosprawnością intelektualną. W artykule 23 konwencji o prawach dziecka można przeczytać: „Państwa-Strony uznają, że dziecko psychicznie lub fizycznie niepełnosprawne powinno mieć zapewnioną pełnię normalnego życia w warunkach honorujących jego godność, umożliwiających osiągnięcie niezależności oraz ułatwiających aktywne uczestnictwo dziecka w życiu społeczeństwa”. Polska podpisała tę konwencję 7 maja 1991 roku (Cytowska 2012: 137). 
W 1997 roku Sejm Rzeczypospolitej Polskiej przyjął Kartę Praw Osób Niepełnosprawnych, w której wzywa Rząd Rzeczypospolitej Polskiej i władze samorządowe do podjęcia działań mających na celu realizację tych praw. W dokumencie tym znalazł się zapis: „[...] osoby, których sprawność fizyczna, psychiczna lub umysłowa trwale lub okresowo utrudnia, ogranicza lub uniemożliwia życie codzienne, naukę, pracę oraz pełnienie ról społecznych, zgodnie z normami prawnymi i zwyczajowymi, mają prawo do niezależnego, samodzielnego i aktywnego życia oraz nie mogą podlegać dyskryminacji” (Uchwała Sejmu Rzeczypospolitej Polskiej z dnia 1 sierpnia 1997 r. - Karta Praw Osób Niepełnosprawnych, M.P. Nr 50, poz. 475). Na rząd Polski nałożono coroczny obowiązek informowania parlamentu o podjętych staraniach w realizacji praw osób niepełnosprawnych.

Kiedy Polska przystępowała w 1991 roku do Rady Europy, a 13 lat później do Unii Europejskiej, musiała uczestniczyć w europejskich projektach, które zobowiązywały kraje członkowskie do wprowadzenia regulacji prawnych, zmierzających w kierunku dobrostanu osób niepełnosprawnych. Jednym z najważniejszych aktów prawnych odwołujących się do realizacji działań antydyskryminacyjnych wobec niepełnosprawnych była Europejska Karta Społeczna. Pod pierwszą wersją tego dokumentu z 1961 roku Polska podpisała się 30 lat później (w 1991 roku, po wstąpieniu do Rady Europy), natomiast drugą wersję (zmienioną) wszystkie kraje członkowskie przyjęły w 1996 roku. W pierwszej wersji Karty z 1961 roku w części II wyróżniono artykuły dotyczące między innymi praw do: bezpiecznych i higienicznych warunków pracy, sprawiedliwego wynagrodzenia, ochrony dzieci i młodocianych, poradnictwa zawodowego, ochrony zdrowia, zabezpieczenia społecznego, szkolenia zawodowego, rehabilitacji oraz readaptacji zawodowej i społecznej osób niepełnosprawnych fizycznie lub umysłowo (Europejska Karta Społeczna sporządzona w Turynie dnia 18 października 1961 r., Dz. U. z 1999 r., Nr 8, poz. 67, ze $\mathrm{zm}$.). W drugiej wersji tego dokumentu zwrócono uwagę między innymi na prawo osób niepełnosprawnych do równych szans i do równego traktowania w sprawach zatrudnienia i wykonywania zawodu, bez dyskryminacji ze względu na płeć, czy na prawo do ochrony przed ubóstwem i marginalizacją społeczną (Europejska Karta Społeczna (zrewidowana) z dnia 3 maja 1996 roku).

Kolejnym znaczącym dokumentem stanowiącym o sytuacji osób z niepełnosprawnością był przyjęty w 2006 roku Plan działań Rady Europy w celu promocji praw i pełnego uczestnictwa osób niepełnosprawnych w społeczeństwie: podnoszenie jakości życia osób niepełnosprawnych w Europie 2006-2015. Główne kierunki działań tego programu zorientowane były na wewnętrzną politykę państw członkowskich Rady Europy, które miały na celu między innymi: zapewnienie osobom $\mathrm{z}$ niepełnosprawnością pełnego uczestnictwa $\mathrm{w}$ życiu politycznym, publicznym i kulturalnym; prawa do edukacji, zatrudnienia, poradnictwa i szkolenia zawodowego; prawa do życia w społeczności lokalnej, opieki zdrowotnej, rehabilitacji, ochrony socjalnej, prawnej i ochrony przed przemocą i wykorzystywaniem. 
Wymogi Rady Europy dotyczące wyrównywania szans i realizacji działań mających na celu integrację społeczną osób z niepełnosprawnością Polska zrealizowała poprzez przyjęcie w 1997 roku Karty Praw Osób Niepełnosprawnych i stworzenie ustawy o rehabilitacji zawodowej i społecznej oraz zatrudnianiu osób niepełnosprawnych. Do dziś (mimo licznych korekt) jest to akt prawny bardzo istotny dla podnoszenia jakości życia, integracji społecznej i zawodowej oraz zatrudniania wspomnianej populacji na otwartym rynku pracy, wprowadza też system dofinansowania pracodawców oraz nakładania kar finansowych na przedsiębiorców, którzy pomimo preferencyjnych dopłat nie zatrudniają osób z orzeczonym stopniem niepełnosprawności (Ustawa z dnia 27 sierpnia 1997 r. o rehabilitacji zawodowej i społecznej oraz zatrudnianiu osób niepełnosprawnych, tekst jedn.: Dz. U. z 2016 r., poz. 2046, ze zm.) (dalej: u.r.z.s.z.). Założenia ustawy zostały omówione szerzej w rozdziale dotyczącym praw osób z niepełnosprawnością w Polsce.

Rozporządzenia Unii Europejskiej zostały zawarte w obowiązującej od 1 stycznia 2011 roku ustawie z dnia 3 grudnia 2010 r. o wdrożeniu niektórych przepisów Unii Europejskiej w zakresie równego traktowania (Dz. U. z 2016 r., poz. 1219). Komisja Europejska od kilku lat zarzuca Polsce zaniedbania w zakresie wdrażania postanowień unijnych. Przeciwko Polsce wszczęto pięć postępowań dotyczących niewdrożenia do polskiego systemu prawnego wspólnotowego prawa antydyskryminacyjego; dwa z nich trafiły do Europejskiego Trybunału Sprawiedliwości (Cytowska 2012: 139). Od kilku lat podejmuje sie próby wprowadzenia w życie projektu stworzonego przez Stowarzyszenie Przyjaciół Integracji, który miał na celu wyrównywanie szans osób niepełnosprawnych. Zaproponowano, aby nazwać go ustawą o niedyskryminacji osób z niepełnosprawnością lub ustawą o wyrównywaniu szans osób z niepełnosprawnością. W Międzynarodowym Dniu Osób Niepełnosprawnych, 3 grudnia 2008 roku, dokument ten został przekazany premierowi, jednak dalsze losy projektu nie są znane (Cytowska 2012: 139).

\section{Niepełnosprawność intelektualna w kontekście ustawy o ochronie zdrowia psychicznego}

Głównym aktem prawnym w Polsce gwarantującym ochronę zdrowia osobom z niepełnosprawnością intelektualną, a także z zaburzeniami psychicznymi, jest ustawa z dnia 19 sierpnia 1994 r. o ochronie zdrowa psychicznego (tekst jedn.: Dz. U. z 2017 r., poz. 882, ze zm.) (dalej: u.o.z.p.). Ustawa ta była kilkakrotnie nowelizowana, a obecnie obowiązuje tekst jednolity z dnia 5 kwietnia 2017 roku (Obwieszczenie Marszałka Sejmu Rzeczypospolitej Polskiej z dnia 5 kwietnia 2017 r. w sprawie ogłoszenia jednolitego tekstu ustawy o ochronie zdrowia psychicznego, Dz. U., poz. 882). Ustawa o ochronie zdrowia psychicznego z 1994 roku została stworzona na podstawie doświadczeń i związanych z nimi ogólnymi normami 
ustawodawstwa psychiatrycznego w krajach Unii Europejskiej oraz Stanach Zjednoczonych. Była także odpowiedzią na ratyfikowanie przez Polskę w 1993 roku Konwencji o Ochronie Praw Człowieka i Obywatela i Podstawowych Wolności, co wynikało z przystąpienia Polski do Rady Europy. Ratyfikowany został również Międzynarodowy Pakt Praw obywatelskich i Politycznych w 1997 roku (Gałecki, Eichstaedt, Bobińska 2012: 525).

Przepisy ustawy o ochronie zdrowia psychicznego z 1994 roku zostały podzielone na 3 grupy i stanowią one kategorię celów, które można ująć następująco:

- promocja zdrowia psychicznego i kształtowanie postaw społecznych;

- opieka zdrowotna i pomoc w środowisku rodzinnym i społecznym;

- ochrona praw osób z zaburzeniami psychicznymi.

Celem pierwszej grupy postanowień ustawy jest zapewnienie promocji zdrowia psychicznego i zapobieganie zaburzeniom psychicznym oraz kształtowanie właściwych postaw społecznych wobec osób z zaburzeniami psychicznymi, przede wszystkim zrozumienia, tolerancji, życzliwości i przeciwdziałania ich dyskryminacji. Celem drugiej grupy przepisów jest zapewnienie osobom z zaburzeniami psychicznymi wielostronnej i powszechnie dostępnej opieki zdrowotnej oraz innych form pomocy, niezbędnych do życia w środowisku społecznym i rodzinnym. Celem trzeciej grupy jest ochrona praw obywatelskich osób z zaburzeniami psychicznymi poprzez wzmocnienie przestrzegania praw określonych w obowiązujących dotychczas ustawach oraz gwarancję praw obywatelskich pacjentów poddanych przymusowemu postępowaniu.

Ustawa o ochronie zdrowia psychicznego z 1994 roku dotyczy trzech kręgów podmiotowych: osób chorych psychicznie, tzn. wykazujących zaburzenia psychotyczne; osób upośledzonych umysłowo oraz osób wykazujących inne zakłócenia czynności psychicznych, które zaliczane są do zaburzeń psychicznych. Należy zauważyć, że wszystkie wyżej opisane przypadki traktowane są w ustawie jako „osoby z zaburzeniami psychicznymi”, a pomimo powszechnie uznanego i promowanego terminu „niepełnoprawność intelektualna” w ustawie, nawet w najnowszej nowelizacji, funkcjonuje stara nomenklatura, czyli „upośledzenie umysłowe”.

Ustawa o ochronie zdrowia psychicznego z 1994 roku w swoich założeniach duży nacisk kładzie na działania zapobiegawcze w zakresie ochrony zdrowia psychicznego, wskazując na konieczność rozwoju różnych form samopomocy rodzinnej, środowiskowej, poradnictwa psychologicznego, socjalnego, dostępności do opieki specjalistycznej. Artykuł 8 u.o.z.p. stanowi:

[...] jednostki organizacyjne i inne podmioty działające na podstawie ustawy o pomocy społecznej [...] w porozumieniu z zakładami psychiatrycznej opieki zdrowotnej organizują na obszarze swojego działania oparcie społeczne dla osób, które z powodu ochrony psychicznej lub upośledzenia umysłowego mają poważne trudności w życiu codziennym, zwłaszcza w kształtowaniu swoich stosunków z otoczeniem, w zakresie edukacji, zatrudnienia oraz w sprawach bytowych. 
Ustawodawca określa, że oparcie społeczne polega w szczególności na rozwijaniu i podtrzymywaniu umiejętności niezbędnych do samodzielnego, aktywnego życia; organizowaniu w środowisku społecznym pomocy ze strony rodziny, innych osób, grup, organizacji społecznych i instytucji; udzielaniu pomocy finansowej, rzeczowej oraz innych świadczeń na zasadach określonych w ustawie o pomocy społecznej.

Zgodnie z zapisem artykułu 4 u.o.z.p. działania zapobiegawcze $\mathrm{w}$ zakresie ochrony zdrowia psychicznego są podejmowane przede wszystkim wobec dzieci, młodzieży, osób starszych i wobec osób znajdujących się w sytuacjach stwarzających zagrożenie dla zdrowia psychicznego. Działania te obejmują w szczególności:

1. stosowanie zasad ochrony zdrowia psychicznego w pracy szkół, placówek systemu oświaty, placówek opiekuńczo-wychowawczych i resocjalizacyjnych oraz w jednostkach wojskowych;

2. tworzenie placówek rozwijających działalność zapobiegawczą, przede wszystkim poradnictwa psychologicznego, oraz placówek specjalistycznych, z uwzględnieniem wczesnego rozpoznawania potrzeb dzieci $z$ zaburzeniami rozwoju psychoruchowego;

3. wspieranie grup samopomocy $\mathrm{i}$ innych inicjatyw społecznych w zakresie ochrony zdrowia psychicznego;

4. rozwijanie działalności zapobiegawczej w zakresie ochrony zdrowia psychicznego przez podmioty lecznicze;

5. wprowadzenie zagadnień ochrony zdrowia psychicznego do programu przygotowania zawodowego osób zajmujących się wychowaniem, nauczaniem, resocjalizacją, leczeniem i opieką, zarządzaniem i organizacją pracy oraz organizacją wypoczynku;

6. podejmowanie badań naukowych służących umacnianiu zdrowia psychicznego i zapobieganiu zaburzeniom psychicznym;

7. uwzględnianie zagadnień zdrowia psychicznego w działalności publicznych środków masowego przekazu, a zwłaszcza w programach radiowych i telewizyjnych.

W zapisie ustawy o ochronie zdrowia psychicznego z 1994 roku pojawia się także pojęcie „świadomej zgody”, której wyjaśnienie zostało zapisane w artykule 3 u.o.z.p. Zgodnie z nim świadoma zgoda oznacza:

swobodnie wyrażoną zgodę osoby z zaburzeniami psychicznymi, która - niezależnie od stanu jej zdrowia psychicznego - jest rzeczywiście zdolna do zrozumienia przekazywanej w dostępny sposób informacji o celu przyjęcia do szpitala psychiatrycznego, jej stanie zdrowia, proponowanych czynnościach diagnostycznych i leczniczych oraz o dających się przewidzieć skutkach tych działań lub ich zaniechania.

Definicja ta dotyczy nie tylko świadomej zgody osoby z zaburzeniami psychicznymi, ale także - jak już wyjaśniono wcześniej - osób z niepełnosprawnością intelektualną. Koncepcja świadomej zgody ma bardzo duże znaczenie w każdym dążeniu osób z zaburzeniami psychicznymi do zachowania indywidualności i autonomii. W przypadku tej grupy osób to pojęcie jest znaczące i doniosłe, ponieważ 
w świetle artykułu 82 kodeksu cywilnego (ustawa z dnia 23 kwietnia 1964 r. Kodeks cywilny, tekst jedn.: Dz. U. z 2017 r., poz. 459, ze zm.) (dalej: k.c.) ważność oświadczenia woli osoby z zaburzeniami psychicznymi może zostać podana w wątpliwość. Kwestionowanie zdolności do wyrażenia świadomej zgody oparte jest na błędnym domniemaniu, że każda osoba z zaburzeniami psychicznymi znajduje się w stanie wyłączającym swobodne lub świadome podjęcie decyzji i wyrażenie woli, co prowadzi do nieuzasadnionego ograniczenia autonomii tych osób. Autonomia osoby z zaburzeniami psychicznymi, a także wynikające z niej prawo do wyrażenia zgody lub odmowy może zostać ograniczone wtedy, gdy osoba ta nie jest w stanie zapewnić sobie istotnego dobra lub gdy zamierza wyrządzić sobie poważną szkodę. Polski ustawodawca $\mathrm{w}$ takiej sytuacji posiłkuje się zasadą paternalizmu. W myśl paternalizmu jednostki, które nie są w stanie kierować swoimi sprawami w obiektywnie dobry dla nich sposób, potrzebują pomocy i kontroli innych jednostek (grup), które są predestynowane lub przynajmniej posiadają kompetencje do sprawowania tej funkcji. W psychiatrii dość często pojawiają się przesłanki do stosowania przymusu zewnętrznego, a każde stosowanie przymusu (pośredniego czy bezpośredniego) jest naruszeniem autonomii jednostki, co musi być uregulowane prawnie. Zgodnie z ustawą o ochronie zdrowia psychicznego z 1994 roku w psychiatrii można wyróżnić paternalizm miękki i twardy. Miękki paternalizm dotyczy osób wykazujących głębokie upośledzenie autonomii, u których występują na przykład objawy psychotyczne lub głęboka niepełnosprawność intelektualna, co świadczy i jest przesłanką o niezdolności do podjęcia świadomej decyzji. Twardy paternalizm dopuszcza ochronę jednostki wbrew jej woli, nawet wtedy, gdy jest ona zdolna do swobodnego i świadomego wyboru. Tego rodzaju sytuacja zdarza się przy stosowaniu wobec niepsychotycznego pacjenta przymusu bezpośredniego albo badania lub przyjęcia bez zgody (Dąbrowski, Pietrzykowski 1997: 27).

W celu zapewnienia ochrony praw pacjentów poddanych przymusowemu postępowaniu u.o.z.p. w artykułach: 23 (hospitalizacja) i 24 (obserwacja) przewiduje odstępstwo od zasady zgody w sytuacji nieodzownej konieczności. Przymus bezpośredni, przymusowe badanie i przyjęcie do szpitala psychiatrycznego na obserwację lub leczenie można zastosować tylko wtedy, gdy z powodu zaburzeń psychicznych lub choroby psychicznej powstaje bezpośrednie zagrożenie, szczególnie cennych dóbr, tzn. życia pacjenta albo życia i zdrowia innych osób, i zachodzi potrzeba podporządkowania autonomii pacjenta dobrom wyższego rzędu (Dąbrowki, Pietrzykowski 1997: 24).

Zgodnie z artykułem 29 u.o.z.p. do szpitala psychiatrycznego może zostać przyjęta osoba z zaburzeniami psychicznymi, której zachowanie wskazuje na to, że nieprzyjęcie do szpitala spowoduje znaczne pogorszenie jej stanu psychicznego, bądź która jest niezdolna do samodzielnego zaspokajania podstawowych potrzeb życiowych, a uzasadnione jest przewidywanie, że leczenie w szpitalu psychiatrycznym przyniesie poprawę jej stanu zdrowia; może ona zostać przymusowo skierowana decyzją sądu opiekuńczego na leczenie szpitalne na wniosek małżonka, krewnych 
w linii prostej, rodzeństwa, jej przedstawiciela ustawowego lub osoby sprawującej nad nią faktyczną opiekę. W stosunku do osoby objętej oparciem społecznym wniosek może złożyć również gmina lub właściwy organ administracji rządowej. Zgodnie z artykułem 30 u.o.z.p. do wniosku, o którym wspomniano powyżej, dołącza się orzeczenie lekarza psychiatry szczegółowo uzasadniające potrzebę leczenia w szpitalu psychiatrycznym. Orzeczenie lekarz psychiatra wydaje na uzasadnione żądanie osoby lub organu uprawnionego do zgłoszenia wniosku o wszczęcie postępowania. Jeżeli treść wniosku lub załączone do wniosku dokumenty uprawdopodabniają zasadność przyjęcia do szpitala psychiatrycznego, a złożenie orzeczenia nie jest możliwe, sąd zarządza poddanie osoby, której dotyczy wniosek, odpowiedniemu badaniu. Badanie to może być przeprowadzone bez jej zgody, jeżeli osoba, której sprawa dotyczy, odmawia poddania się badaniu. O wypisaniu ze szpitala psychiatrycznego osoby w nim przebywającej, zgodnie $\mathrm{z}$ artykułem 35 u.o.z.p., decyduje ordynator (lekarz kierujący oddziałem), jeżeli uzna, że ustały przewidziane w niniejszej ustawie przyczyny przyjęcia i pobytu tej osoby w szpitalu psychiatrycznym. Osoba ta może, za swoją później wyrażoną zgodą, pozostać w szpitalu psychiatrycznym, jeżeli w ocenie lekarza jej dalszy pobyt w tym szpitalu jest celowy. W rozdziale 4 (artykuł 38) u.o.z.p. znalazł się zapis mówiący, że:

jeżeli osoba, która wskutek choroby psychicznej lub upośledzenia umysłowego nie jest zdolna do zaspokajania podstawowych potrzeb życiowych i nie ma możliwości korzystania z opieki innych osób oraz potrzebuje stałej opieki i pielęgnacji, lecz nie wymaga leczenia szpitalnego, może być za jej zgodą lub za zgodą jej przedstawiciela ustawowego przyjęta do domu pomocy społecznej.

W sytuacji, gdy osoba z zaburzeniami psychicznymi lub jej przedstawiciel ustawowy nie wyrażają zgody na skierowanie jej do domu pomocy społecznej, a brak opieki zagraża życiu tej osoby, organ do spraw pomocy społecznej może wystąpić do sądu opiekuńczego miejsca zamieszkania tej osoby z wnioskiem o przyjęcie do domu pomocy społecznej bez jej zgody, zgodnie z artykułem 39 u.o.z.p. Z wnioskiem może wystąpić również kierownik szpitala psychiatrycznego, jeżeli przebywająca w nim osoba jest niezdolna do samodzielnego zaspokajania podstawowych potrzeb życiowych, a wymaga stałej opieki i pielęgnacji, natomiast nie wymaga dalszego leczenia $w$ tym szpitalu. $\mathrm{W}$ artykule 39 u.o.z.p. mowa również o tym, że jeżeli osoba wymagająca skierowania do domu pomocy społecznej ze względu na swój stan psychiczny nie jest zdolna do wyrażenia na to zgody, o jej skierowaniu do domu pomocy społecznej orzeka sąd opiekuńczy. Zgodnie z artykułem 42 u.o.z.p. w sytuacji, w której dana osoba została przyjęta do domu pomocy społecznej bez jej zgody, przedstawiciel ustawowy, małżonek, krewni w linii prostej, rodzeństwo lub osoba sprawująca nad nią faktyczną opiekę mogą wystąpić do sądu opiekuńczego o zmianę orzeczenia o przyjęciu do domu pomocy społecznej. Z takim wnioskiem może wystąpić także kierownik domu pomocy społecznej, jeżeli uzna, że zmieniły się okoliczności uzasadniające o przyjęciu tej osoby do domu pomocy społecznej bez jej zgody. 
Należy podkreślić, że zgodnie z artykułem 43 u.o.z.p. do szpitala psychiatrycznego i domu pomocy społecznej przeznaczonego dla osób chorych psychicznie lub upośledzonych umysłowo ma prawo wstępu o każdej porze sędzia w celu kontroli legalności przyjęcia i przebywania $\mathrm{w}$ takim szpitalu lub domu pomocy społecznej osób z zaburzeniami psychicznymi, przestrzegania ich praw oraz kontroli warunków, w jakich przebywają. Artykuł 48 u.o.z.p. gwarantuje, że postępowanie przed sądem opiekuńczym w sprawach określonych ustawą jest wolne od kosztów sądowych oraz, że sąd może ustanowić dla osoby, której postępowanie dotyczy bezpośrednio, adwokata z urzędu, nawet bez złożenia wniosku, jeżeli osoba ta ze względu na stan zdrowia psychicznego nie jest zdolna do złożenia wniosku, a sąd uzna udział adwokata w sprawie za potrzebny.

Można zauważyć, że ustawa o ochronie zdrowia psychicznego z 1994 roku z jednej strony koncentruje się na potrzebach zdrowotnych osób chorych psychicznie zarówno zagrażających sobie i innym, jak i wymagających leczenia; ogranicza prawo odmowy leczenia pacjentów przyjętych bez zgody; określa lekarza jako osobę decydującą o wypisaniu pacjenta przebywającego w szpitalu na mocy postępowania sądowego, a także odrzuca ideę, że zagrożenie życia lub zdrowia może być jedynym kryterium przymusowej hospitalizacji. Z drugiej strony określa względnie precyzyjne ustawowe kryteria stosowania środków przymusu (przymusu bezpośredniego, przymusowego badania, przyjęcia i leczenia), przewiduje jasny system gwarancji administracyjno-medycznych, sądowo-procesowych i sądowo-kontrolnych, praktycznie ogranicza przymusowe leczenie do ram szpitala psychiatrycznego, nie rozszerzając go na leczenie ambulatoryjne (Gałecki, Eichstaedt, Bobińska 2012: 530).

\section{Wybrane aspekty dotyczące zagadnienia niepełnosprawności intelektualnej w kontekście prawa cywilnego}

Głównymi zagadnieniami dotyczącymi niepełnosprawności intelektualnej z zakresu prawa cywilnego są: zdolność do czynności prawnych oraz kwestia ubezwłasnowolnienia, popełnianie czynów niedozwolonych i odpowiedzialność za wyrządzoną szkodę, a także wady oświadczenia woli.

\section{Zdolność do czynności prawnych oraz kwestia ubezwłasnowolnienia}

Artykuł 8 k.c. stanowi: „każdy człowiek od chwili urodzenia ma zdolność prawną”, zgodnie z artykułem 11 k.c.: „pełną zdolność do czynności prawnych nabywa się z chwilą uzyskania pełnoletniości", czyli w momencie ukończenia osiemnastu lat. W artykule 12 k.c. podkreśla się jednak, że „zdolności nie mają osoby, które nie ukończyły lat trzynastu, oraz osoby ubezwłasnowolnione całkowicie”. Ubezwłasnowolnienie jest postępowaniem sądowym mającym na celu pozbawienie 
lub ograniczenie zdolności prawnych osoby, której dotyczy (Łuniewski 1950: 55). Należy zwrócić uwagę na fakt, że ubezwłasnowolnienie jest środkiem prawnym mającym na celu ochronę interesów osoby, która ma być ubezwłasnowolniona (Uszkiewiczowa 1973: 31-40). Zgodnie z artykułem 13 k.c.:

$\$ 1$. Osoba, która ukończyła lat trzynaście, może być ubezwłasnowolniona całkowicie, jeżeli wskutek choroby psychicznej, niedorozwoju umysłowego albo innego rodzaju zaburzeń psychicznych, w szczególności pijaństwa lub narkomanii, nie jest w stanie kierować swym postępowaniem.

$\$ 2$. Dla ubezwłasnowolnionego całkowicie ustanawia się opiekę, chyba że pozostaje on jeszcze pod władzą rodzicielską.

Reasumując, osoba, której ma dotyczyć ubezwłasnowolnienie, musi być chora psychicznie, niepełnosprawna intelektualnie lub przejawiać innego rodzaju zaburzenia psychiczne, które mogą wiązać się z uzależnieniem od alkoholu lub innych substancji psychoaktywnych i wskutek tych zaburzeń nie jest w stanie kierować swoim postępowaniem (Pazdan 1997: 59).

Zgodnie z artykułem 14 k.c.: „czynność prawna dokonana przez osobę, która nie ma zdolności do czynności prawnych, jest nieważna”, jeżeli jednak osoba ta "zawarła umowę należącą do umów powszechnie zawieranych w drobnych bieżących sprawach życia codziennego, umowa taka staje się ważna $\mathrm{z}$ chwilą jej wykonania, chyba, że pociąga za sobą rażące pokrzywdzenia osoby niezdolnej do czynności prawnych". Według zapisu artykułu 16 k.c.:

osoba pełnoletnia może być ubezwłasnowolniona częściowo z powodu choroby psychicznej, niedorozwoju umysłowego albo innego rodzaju zaburzeń psychicznych, w szczególności pijaństwa lub narkomanii, jeżeli stan tej osoby nie uzasadnia ubezwłasnowolnienia całkowitego, lecz potrzebna jest pomoc do prowadzenia jej spraw.

Dla takiej osoby ustanawia się kuratelę. Artykuł 15 k.c. stanowi, że osoby ubezwłasnowolnione częściowo mają ograniczoną zdolność do czynności prawnych, podobnie jak osoba małoletnia, która ukończyła trzynaście lat. W artykule 545 kodeksu postępowania cywilnego (ustawa z dnia 17 listopada 1964 r. - Kodeks postępowania cywilnego, tekst jedn.: Dz. U. z 2016 r., poz. 1822, ze zm.) wymieniono osoby uprawnione do złożenia wniosku o ubezwłasnowolnienie, są nimi: małżonek osoby, której dotyczy wniosek o ubezwłasnowolnienie, krewni w linii prostej i rodzeństwo lub jej przedstawiciel ustawowy. Podstawą do wydania przez sąd postanowienia dotyczącego ubezwłasnowolnienia jest sposób, w jaki osoba, która ma zostać ubezwłasnowolniona, kieruje swoimi postępowaniem, czy zagraża swojemu dobru lub dobru otoczenia, czy jej stan lub choroba wpływa na rozumienie tego, co robi, czy oddziałuje na jej wolę, czy stanowi zagrożenie dla siebie lub otoczenia (Hajdukiewicz 2004: 63). Podstawą do całkowitego ubezwłasnowolnienia w kwestii niepełnosprawności intelektualnej jest stan głębokiej niepełnoprawności intelektualnej, natomiast w przypadku częściowego ubezwłasnowolnienia - stany 
niepełnosprawności intelektualnej, które nie są tak nasilone, by uzasadniały ubezwłasnowolnienie całkowite (Uszkiewiczowa 1973: 31-40).

\section{Czyny niedozwolone i odpowiedzialność za wyrządzoną szkodę}

Osoby niepełnosprawne intelektualnie mogą dopuścić się czynów niedozwolonych. Podstawową zasadą odpowiedzialności z tytułu czynów niedozwolonych jest zasada winy, która wynika z artykułu 415 k.c. By ponosić odpowiedzialność za czyn, musi zaistnieć szkoda, czyn sprawczy będący winą oraz związek przyczynowy pomiędzy czynem a szkodą (Banaszczyk 1997: 758). Zarzut takiego zachowania można postawić jedynie osobie, która działała $\mathrm{z}$ rozeznaniem, czyli wtedy, kiedy można jej przypisać winę. Artykuł 425 k.c. stanowi: „osoba, która $\mathrm{z}$ jakichkolwiek powodów znajduje się $\mathrm{w}$ stanie wyłączającym świadome albo swobodne powzięcie decyzji i wyrażenie woli, nie jest odpowiedzialna za szkodę w tym stanie wyrządzoną". Zgodnie z zapisem w artykule 82 k.c. stanem takim jest: „niedorozwój umysłowy”, „choroby psychiczne lub co najmniej przejściowe zaburzenia psychiczne wynikające z przyczyn chorobowych lub innych czynników wewnętrznych". Fakt ubezwłasnowolnienia osoby, która wyrządziła szkodę, nie ma znaczenia dla postawienia zarzutu winy. Jak słusznie zauważa Zbigniew Banaszczyk, nawet osoba całkowicie ubezwłasnowolniona może w chwili wyrządzenia szkody działać z pełnym rozeznaniem (Banaszczyk 1997: 820). Odpowiedzialność za szkodę jest utrzymana u osoby, która świadomie i swobodnie podejmuje decyzję i wyraża wolę (Hajdukiewicz 2004: 63).

Może dojść do sytuacji, w której osoba ubezwłasnowolniona prawomocnym orzeczeniem sądu cywilnego będzie oskarżona o popełnienie przestępstwa. W wyroku z dnia 25 lutego 2009 roku (II KK 316/08) Sąd Najwyższy orzekł, że ubezwłasnowolnienie samo w sobie nie oznacza niepoczytalności sprawcy czynu zabronionego, będącego ubezwłasnowolnionym. Sytuacja taka powoduje jedynie dopuszczenie dowodu z opinii biegłych psychiatrów celem ustalenia poczytalności oskarżonego, albowiem w zaistniałej sytuacji powstaje wątpliwość co do stanu zdrowia psychicznego oskarżonego.

\section{Czynności prawne i wady oświadczenia woli}

W kwestiach czynności prawnych i wad oświadczenia woli bardzo istotne są artykuły 82 i 87 k.c.. Z przepisów tych wynika, że nieważne jest oświadczenie woli złożone przez osobę, która z jakichkolwiek przyczyn znajdowała się w stanie wyłączającym świadome lub swobodne powzięcie decyzji i wyrażenie woli. Stanem takim jest, jak już wspomniano wcześniej, stan głębokiej niepełnosprawności intelektualnej. Należy zauważyć, że w przypadku niepełnosprawności intelektualnej niezwykle istotne wydają się być aspekty ważności oświadczenia woli, czyli świadomość 
podejmowanej decyzji, swoboda i możliwość bezpośredniego wyrażenia - słownie, pisemnie lub w sposób dorozumiany (gestem, mimiką) swojej woli. Osoby niepełnosprawne intelektualnie, by mogły wyrazić wolę w sposób ważny, muszą rozumieć swoją decyzję, a także przewidywać jej skutki prawne. Wybory powinny być dokonywane w sposób swobodny, a należy zwrócić uwagę, że osoby niepełnosprawne intelektualnie są podatne na sugestie, łatwiej ulegają naciskom otoczenia, poszukują akceptacji, przy czym często nie potrafią w sposób racjonalny przewidzieć konsekwencji swoich decyzji. Chcąc spełnić oczekiwania otoczenia i jednocześnie być docenionym, osoby z niepełnosprawnością intelektualną mogą ulegać presji otoczenia wbrew własnym korzyściom. Mogą także wykazywać większą skłonność do zachowań zgodnych z poleceniem lub kontekstem sytuacji. Racjonalna ocena podejmowanej decyzji jest $\mathrm{w}$ dużej mierze zależna od sprawności funkcjonowania intelektualnego. Stan niepełnosprawności intelektualnej, zwłaszcza lekkiego stopnia, nie wyklucza zdolności podejmowania racjonalnych decyzji, jeśli sprawa, której decyzja dotyczy, oraz konsekwencje owej decyzji przedstawione zostaną w sposób przystępny i zrozumiały dla danej osoby. Reasumując, jedynie stan głębokiej niepełnosprawności intelektualnej wyklucza możliwość podjęcia świadomej lub swobodnej decyzji i wyrażenia woli (Gałecki, Eichstaedt, Bobińska 2012: 537).

\section{Wybrane aspekty dotyczące zagadnienia niepełnosprawności intelektualnej w kontekście orzecznictwa rentowego}

W zakresie form zabezpieczenia finansowego obywatela przez państwo można wyróżnić świadczenia rentowe i orzecznictwo o niepełnosprawności. Niepełnosprawność intelektualna jest stanem niepełnego rozwoju intelektualnego objawiającego się od najmłodszych lat rozwojowych. Osoby z niepełnosprawnością intelektualną zdolne do wypełnienia obowiązków społecznych w zakresie zarobkowania, a więc osoby z niepełnosprawnością intelektualną w stopniu lekkim, mogą korzystać ze świadczeń rentowych w sytuacji, gdy z przyczyn chorób współtowarzyszących utracą zdolność do zarobkowania. Osoby z niepełnosprawnością intelektualną w stopniu głębszym (niepełnosprawność intelektualna w stopniu umiarkowanym lub znacznym) nie są zdolne do podjęcia aktywności zawodowej, a stan niepełnosprawności intelektualnej zauważany jest od najwcześniejszych lat rozwojowych. W sytuacji dzieci w wieku do 16 roku życia orzeka się tzw. niepełnosprawność dotyczy to przypadku stwierdzenia naruszenia sprawności fizycznej lub psychicznej o przewidywalnym okresie trwania powyżej dwunastu miesięcy i konieczności zapewnienia całkowitej opieki i pomocy osób trzecich. W takich sytuacjach rodzice dziecka mogą otrzymać tzw. zasiłek pielęgnacyjny. U osób powyżej 16 roku życia orzeka się o stopniu niepełnosprawności (Zyss 2009: 218). Wyróżnia się 3 stopnie niepełnosprawności - lekki, umiarkowany i znaczny. Do otrzymania świadczeń uprawnia co najmniej umiarkowany stopień niepełnosprawności. Do 
celów rehabilitacyjnych, udzielania pomocy społecznej, korzystania z uprawnień przysługujących osobom $\mathrm{z}$ niepełnosprawnością świadczenia rentowe są niewystarczające. Ustawa o rehabilitacji zawodowej i społecznej oraz zatrudnianiu osób niepełnosprawnych z 1997 roku wyróżnia 3 stopnie niepełnosprawności: lekki, umiarkowany i znaczny. Zaliczenie do danego stopnia niepełnosprawności odbywa się drogą orzeczenia wydawanego przez powiatowe zespoły do spraw orzekania przy powiatowych centrach pomocy rodzinie. Zgodnie $\mathrm{z}$ artykułem 4 u.r.z.s.z.:

Do znacznego stopnia niepełnosprawności zalicza się osobę mającą naruszoną sprawność organizmu, niezdolną do pracy albo zdolną do pracy jedynie w warunkach pracy chronionej i wymagającą, w celu pełnienia ról społecznych, stałej lub długotrwałej opieki i pomocy innych osób w związku z niezdolnością do samodzielnej egzystencji. Do umiarkowanego stopnia niepełnosprawności zalicza się osobę z naruszoną sprawnością organizmu, niezdolną do pracy albo zdolną do pracy jedynie w warunkach pracy chronionej lub wymagającej czasowej albo częściowej pomocy innych osób w celu pełnienia ról społecznych. Do lekkiego stopnia niepełnosprawności zalicza się osobę o naruszonej sprawności organizmu, powodującej w sposób istotny obniżenie zdolności do wykonywania pracy, w porównaniu do zdolności, jaką wykazuje osoba o podobnych kwalifikacjach zawodowych z pełną sprawnością psychiczną i fizyczną, lub mającą ograniczenia w pełnieniu ról społecznych dające się kompensować przy pomocy wyposażenia w przedmioty ortopedyczne, środki pomocnicze lub środki techniczne.

U osób, u których stwierdza się poza niepełnosprawnością intelektualną również inne rodzaje niepełnosprawności (np. uszkodzenia narządu słuchu, wzroku, ruchu, choroby psychiczne, schorzenia neurologiczne), ustala się zakres poszczególnych niepełnosprawności (Zyss 2009: 219-222).

Aktualnie obowiązująca ustawa $\mathrm{z}$ dnia 17 grudnia 1998 r. o emeryturach i rentach z Funduszu Ubezpieczeń Społecznych (tekst jedn.: Dz. U. z 2017 r., poz. 1383, ze zm.) nie zawiera żadnych wytycznych orzeczniczych, które określałyby w sposób jednoznaczny, w jaki sposób dane schorzenie wpływa i ogranicza zdolność pacjenta do zatrudnienia. Procedura orzekania w zakresie przypisywania danemu schorzeniu o danym nasileniu sprecyzowanego znaczenia orzeczniczego została przerzucona na decyzję lekarzy ZUS oraz biegłych sądowych (Zyss 2009: 232). Do niedawna obowiązujące rozporządzenie Rady Ministrów z dnia 15 maja 1989 r. w sprawie uprawnień do wcześniejszej emerytury pracowników opiekujących się dziećmi wymagającymi stałej opieki (Dz. U. Nr 28, poz. 149) było jedynym aktem prawnym, który wymieniał schorzenia i przypisywał im określone znaczenie orzecznicze (Zyss 2009: 232).

Jedno z opisywanych zagadnień w rozporządzeniu RM z dnia 15 maja 1989 roku to schorzenie psychiczne, którego głównym objawem był deficyt intelektualny należała do niego niepełnosprawność intelektualna. Orzecznictwo rentowe zajmowało się sprawnością intelektualną poniżej 90 punktów ilorazu inteligencji. Według rozporządzenia niepełnosprawność intelektualna została podzielona na sześć podzakresów: inteligencja poniżej normy (wartość ilorazu inteligencji 80-89) i pogranicze 
„upośledzenia” (dawna ociężałość umysłowa, wartość ilorazu inteligencji 70-79), niepełnosprawność intelektualna stopnia lekkiego, umiarkowanego, znacznego i głębokiego. Podstawą do orzeczenia całkowitej niezdolności do pracy była niepełnosprawność intelektualna co najmniej umiarkowanego stopnia. Głębsze stopnie niepełnosprawności przeważnie powiązane z deficytami neurologicznymi lub padaczką były powodem orzeczenia u pacjenta, poza całkowitą niezdolnością do pracy, także niezdolności do samodzielnej egzystencji. Osoba z lekką niepełnosprawnością intelektualną mogła wymagać opieki osób trzecich jedynie przy współwystępowaniu innych ciężkich schorzeń - bardzo poważnie utrudniających sprawność ustroju. Sama niepełnosprawność intelektualna lekkiego stopnia była podstawą do orzeczenia jedynie częściowej niezdolności do pracy. Pogranicze niepełnoprawności intelektualnej lub inteligencja poniżej przeciętnej nie stanowiły przesłanki do orzekania o choćby częściowej niezdolności do pracy. W sytuacjach, gdy deficyt intelektualny nawet niewielkiego stopnia współwystępował z deficytem w zakresie narządu słuchu, ruchu, wzroku czy zaburzeniem lub chorobą psychiczną, mogła zaistnieć przesłanka do orzeczenia całkowitej niezdolności do pracy. Wśród bardzo często współwystępujących z niepełnosprawnością intelektualną zaburzeń psychicznych należy wymienić zaburzenia zachowania i zaburzenia emocjonalne, które potwierdzone koniecznością leczenia mogły dać podstawy do orzeczenia nawet całkowitej niezdolności do pracy (Zyss 2009: 235). Poruszając kwestię świadczeń finansowych, jakie otrzymać mogą osoby niepełnosprawne intelektualne, a także ich rodziny, należy wspomnieć, że wytyczne zawarte $\mathrm{w}$ powyżej omówionym rozporządzeniu mają zastosowanie w orzekaniu w zakresie renty rodzinnej i socjalnej (Zyss 2009: 240). W aspekcie niepełnosprawności intelektualnej renta rodzinna przysługuje w sytuacji śmierci jednego z rodziców bez względu na wiek, jeżeli dziecko jest całkowicie niezdolne do pracy oraz samodzielnej egzystencji. Renta socjalna jest świadczeniem finansowym przysługującym osobom, które zachorowały w okresie dzieciństwa i młodości. Należy zwrócić uwagę jeszcze na fakt, że osobom ciężko chorym, wymagającym opieki drugiej osoby, przysługuje świadczenie $\mathrm{w}$ formie dodatku lub zasiłku pielęgnacyjnego. Przyznawany jest on osobom, które zostały uznane za całkowicie niezdolne do pracy i samodzielnej egzystencji (znaczny stopień niepełnosprawności). Zasiłek pielęgnacyjny przysługuje bez względu na wysokość dochodów na członka rodziny, nie przysługuje natomiast osobom przebywającym w domu dziecka, domach opieki społecznej, zakładach opiekuńczo-leczniczych czy zakładach opiekuńczo-wychowawczych. Zasiłek pielęgnacyjny może zostać przyznany w przypadku bardzo ciężkich schorzeń, jak na przykład niepełnosprawność intelektualna co najmniej umiarkowanego stopnia lub lżejsza niepełnosprawność intelektualna, ale przebiegająca z zaburzeniami neurologicznymi (padaczką, niedosłuchem, głuchotą, niedowidzeniem, ślepotą, porażeniem mózgowo-rdzeniowym) lub zaburzeniami psychicznymi znacznie utrudniającymi codzienne funkcjonowanie. Zasiłek pielęgnacyjny jest świadczeniem o charakterze pomocniczym, wypłacanym przez opiekę społeczną, natomiast dodatek pielęgnacyjny jest świadczeniem o charakterze ubezpieczeniowym i wypłacany jest przez Zakład Ubezpieczeń 
Społecznych. Dana osoba może otrzymywać albo zasiłek, albo dodatek pielęgnacyjny (Zyss 2009: 216-217).

\section{Wybrane aspekty dotyczące zagadnienia niepełnosprawności intelektualnej w kontekście prawa karnego}

Niestety nie istnieją konkretne dane, które mogłyby zobrazować zjawisko popełniania przestępstw $\mathrm{w}$ Polsce przez osoby $\mathrm{z}$ niepełnosprawnością intelektualną. W tym miejscu można przytoczyć jedynie badania amerykańskie, które pokazują, że osoby z niepełnosprawnością intelektualną nie popełniają przestępstw częściej niż osoby sprawne intelektualnie (Richard-Devantoy et al. 2009 za: Gałecki, Eichstaedt, Bobińska 2012: 530). Z kolei w innych, również amerykańskich (Caldera et al. 2009 za: Gałecki, Eichstaedt, Bobińska 2012: 530) badaniach pojawiła się słuszna teza, że ze względu na cechy charakterologiczne osób niepełnosprawnych, takie jak podatność na sugestie i chęć akceptacji przez otoczenie, istnieje duże prawdopodobieństwo, że będą one przyznawać się do czynów, których nie popełniły. Osoby niepełnosprawne intelektualnie najczęściej nie działają same, raczej wypełniają czyjeś zadania. Przestępstwa przez nie popełniane przeważnie są nieplanowane i wynikają z zaburzonej kontroli zachowań impulsywnych, nieumiejętności radzenia sobie z emocjami i sytuacjami stresowymi oraz braku umiejętności przewidywania konsekwencji. Często więc mogą wynikać ze strachu, złości lub paniki. Niskie zdolności intelektualne, a więc także niskie zdolności planowania i przewidywania powodują, że przestępcy z niepełnosprawnością intelektualną częściej są ujmowani, mają mniejszą szansę na postępowanie we własnej obronie i częściej przyznają się do winy (Caldera et al. 2009 za: Gałecki, Eichstaedt, Bobińska 2012: 531).

$\mathrm{W}$ przedostatnim podrozdziale zostaną przedstawione najważniejsze zagadnienia związane $\mathrm{z}$ opiniowaniem sądowo-psychiatrycznym w sytuacjach, w których postępowanie karne dotyczy osoby z niepełnosprawnością intelektualną.

Ustalenie poczytalności sprawcy z punktu widzenia norm prawa karnego jest bardzo istotne, ponieważ jest to jedyna z okoliczności wyłączających winę. Artykuł $1 \S 3$ kodeksu karnego (ustawa $\mathrm{z}$ dnia 6 czerwca 1997 r. - Kodeks karny, tekst jedn.: Dz. U. z 2016 r., poz. 1137, ze zm.) (dalej: k.k.) mówi, że: „Nie popełnia przestępstwa sprawca czynu zabronionego, jeżeli nie można mu przypisać winy w czasie czynu" (łac. nullum crimen sine culpa - nie ma przestępstwa bez winy). Kluczowym dla opiniowania sądowo-psychiatrycznego jest artykuł 31 k.k., zgodnie z którym:

$\$ 1$. nie popełnia przestępstwa, kto z powodu choroby psychicznej, upośledzenia umysłowego lub innego zakłócenia czynności psychicznych, nie mógł w czasie czynu rozpoznać jego znaczenia lub pokierować swoim postępowaniem.

$\$ 2$. Jeżeli w czasie popełnienia przestępstwa zdolność rozpoznania znaczenia czynu lub kierowania postępowaniem była w znacznym stopniu ograniczona, sąd może zastosować nadzwyczajne złagodzenia kary. 
Zgodnie z artykułem 202 kodeksu postępowania karnego (ustawa z dnia 6 czerwca 1997 r. - Kodeks postępowania karnego, tekst jedn.: Dz. U. z 2017 r., poz. 1904, ze zm.) (dalej: k.p.k.), aby móc odpowiedzieć na pytania dotyczące kwestii występowania u sprawcy czynu zabronionego niepełnosprawności intelektualnej, powoływani są biegli w celu sporządzenia opinii sądowo-psychiatrycznej:

$\$ 1$. W celu wydania opinii o stanie zdrowia psychicznego oskarżonego sąd, a w postępowaniu przygotowawczym prokurator, powołuje co najmniej dwóch biegłych lekarzy psychiatrów.

$\S 2$. Na wniosek psychiatrów do udziału w wydaniu opinii powołuje się ponadto biegłego lub biegłych innych specjalności.

$\$ 3$. Do udziału w wydaniu opinii o stanie zdrowia psychicznego oskarżonego, w zakresie zaburzeń preferencji seksualnych, sąd, a w postępowaniu przygotowawczym prokurator, powołuje biegłego lekarza seksuologa.

$\$ 4$. Biegli nie mogą pozostawać ze sobą w związku małżeńskim ani w innym stosunku, który mógłby wywołać uzasadnioną wątpliwość co do ich samodzielności.

$\$ 5$. Opinia biegłych powinna zawierać stwierdzenia dotyczące zarówno poczytalności oskarżonego w chwili popełniania czynu, jak i jego aktualnego stanu zdrowia psychicznego oraz zdolności do udziału w postępowaniu [...].

Określenie poziomu intelektualnego na potrzeby badania sądowo-psychiatrycznego powinno odbywać się przez zebranie wywiadu, przeprowadzenie badania psychiatrycznego oraz sprawdzenie funkcjonowania intelektualnego metodami testowymi (Przybysz 2003: 27). Zgodnie z artykułem $202 \$ 2$ k.p.k. zadanie to wykonywane jest przez biegłego psychologa, którego powołuje organ procesowy na wniosek biegłych psychiatrów.

W kontekście niepełnosprawności intelektualnej podstawę do oceny poczytalności jako zniesionej w chwili czynu daje niepełnosprawność stopnia głębokiego bądź stwierdzenie obecności choroby psychicznej w znaczeniu psychozy lub krótkotrwałych, przemijających zakłóceń czynności psychicznych będących krótkotrwałymi psychozami, które mogą być stanami współistniejącymi z niepełnosprawnością intelektualną, również lżejszego stopnia. Poczy talność ograniczona w stopniu znacznym może zostać orzeczona w niepełnosprawności intelektualnej, która nie daje podstaw do stwierdzenia niepoczytalności, ale ogranicza ją w stopniu znacznym. Należy podkreślić, że zarówno niepoczytalność, jak i poczytalność ograniczoną w stopniu znacznym zawsze orzeka się w czasie czynu i w odniesieniu do konkretnego czynu zabronionego (Filar 2006: 99). Na stwierdzenie stanu niepoczytalności składają się dwie składowe: psychologiczna i psychiatryczna. Zgodnie z tym czynnik intelektu odpowiada za rozpoznanie znaczenia czynu, a alternatywnie mu przeciwstawny czynnik woli za możliwość kierowania swoim intelektem (Filar 2006: 98). Oba człony - psychiatryczny i psychologiczny, wzajemnie się ograniczają, ponieważ nie każde zaburzenie psychiczne daje podstawę do oceny niepoczytalności, ale tylko takie, które pozbawia sprawcę zdolności rozpoznania 
znaczenia czynu lub pokierowania swoim postępowaniem, natomiast brak tych zdolności musi być spowodowany przez zaburzenia wymienione w członie psychiatrycznym. W pewnych przypadkach, mimo sprawnego intelektu i niezaburzonej świadomości, zaburzenia dotyczące sfery woli zakłócają kierowanie postępowaniem. Błędnym byłoby sformułowanie odwrotne, że sprawca pozbawiony zdolności rozpoznawania czynu może kierować swoim postępowaniem (Hajdukiewicz 2007: 116).

Ocena poczytalności sprawcy, z punktu widzenia medycyny, bardzo często jest sprawą niejednoznaczną i mogącą budzić wątpliwości i kontrowersje. Zdarza się, że biegli psychiatrzy powoływani przez sąd lub prokuraturę nie potrafią jednoznacznie ocenić poczytalności sprawcy czynu w jednym badaniu ambulatoryjnym. Podobnie wygląda kwestia określenia stopnia niepełnosprawności, pojmowania reguł społecznych i sposobu funkcjonowania. W konsekwencji może to przesądzić o orzeczeniu poczytalności zniesionej lub ograniczonej w stopniu znacznym. Zgodnie $\mathrm{z}$ artykułem 203 k.p.k. w sytuacji, gdy to niezbędnie konieczne, może zajść przymus orzeczenia obserwacji sądowo-psychiatrycznej.

Jednym $\mathrm{z}$ najtrudniejszych zadań zarówno dla opiniujących biegłych, jak i sądu jest orzekanie $\mathrm{w}$ sprawach odpowiedzialności w stanie niepoczytalności lub poczytalności ograniczonej, która wystąpiła w wyniku spożycia alkoholu lub innego środka odurzającego. Zgodnie z artykułem $31 \S 3$ k.k. niepoczytalność lub poczytalność ograniczona nie mają zastosowania, gdy: „sprawca wprawiając się w stan nietrzeźwości lub odurzenia przewidywał wyłączenie lub ograniczenie jego poczytalności albo mógł je przewidzieć". Zgodnie z komentarzem Mariana Filara nie można przypisać niepoczytalności lub poczytalności ograniczonej w stopniu znacznym, gdy sprawca doprowadził się w stan nietrzeźwości sam, dobrowolnie umyślnie oraz musiał lub co najmniej mógł przewidzieć następstwa wprowadzenia się w ten stan (Filar 2006: 101). W związku z tym artykuł $31 \S 3$ k.k.:

nie ma więc zastosowania do osób, które odurzone zostały wbrew własnej woli lub których odurzenie było wynikiem nadzwyczajnych i nietypowych procesów fizjologicznych (upojenie patologiczne i na podłożu patologicznym). W wypadkach tych bowiem użycie alkoholu jest jedynie czynnikiem zaostrzającym istniejący już stan patologiczny (np. uszkodzenia mózgu, niedorozwój umysłowy), nie zaś samoistną przyczyną utraty lub ograniczenia poczytalności (Filar 2006: 101-102).

W sprawach dotyczących nieletnich do kwestii związanych z niepełnosprawnością intelektualną zastosowanie ma artykuł 12 ustawy z dnia 26 października $1982 \mathrm{r}$. o postępowaniu w sprawach nieletnich (tekst jedn.: Dz. U. z 2016 r., poz. 1654, ze zm.), który mówi, że:

w razie stwierdzenia u nieletniego upośledzenia umysłowego, choroby psychicznej lub innego zakłócenia czynności psychicznych bądź nałogowego używania alkoholu albo innych środków w celu wprowadzenia się w stan odurzenia, sąd rodzinny może orzec umieszczenie nieletniego w szpitalu psychiatrycznym lub innym odpowiednim 
zakładzie leczniczym. Jeżeli zachodzi potrzeba zapewnienia nieletniemu jedynie opieki wychowawczej, sąd może orzec umieszczenie go w młodzieżowym ośrodku wychowawczym, a w przypadku, gdy nieletni jest upośledzony umysłowo w stopniu głębokim i wymaga jedynie opieki - w domu pomocy społecznej.

Krystyna Gromek do środków leczniczo-wychowawczych zalicza:

a) środki lecznicze: obejmujące szpitale psychiatryczne i inne odpowiednie zakłady lecznicze przeznaczone dla osób nieletnich skierowanych z powodu następujących przyczyn dodatkowych:

- niezależnych od postępowania nieletniego, tj. upośledzenia umysłowego, choroby psychicznej i innego zakłócenia czynności psychicznych;

- zależnych od postępowania nieletniego, tj. nałogowego używania alkoholu albo innych środków w celu wprowadzenia się w stan odurzenia;

b) środki opiekuńcze: obejmujące domy pomocy społecznej, przeznaczone dla osób nieletnich wymagających jedynie specjalistycznej opieki oligofrenopedagogicznej z powodu upośledzenia umysłowego w stopniu głębokim;

c) środki opiekuńczo-wychowawcze: obejmujące placówki opiekuńczo-wychowawcze, przeznaczone dla osób nieletnich wymagających specjalistycznych oddziaływań rewalidacyjno-resocjalizacyjnych (Gromek 2001: 136).

Pomimo braku konkretnych danych przedstawiających liczbę osadzonych w więzieniach osób z niepełnosprawnością intelektualną lub chorych psychicznie temat nie pozostaje w sferze tabu. W zeszłym roku Biuro Rzecznika Praw Obywatelskich przeprowadziło badania, w toku których znaleziono w więzieniach osoby niepełnosprawne intelektualnie lub chore psychiczne, które nie powinny tam trafić. Po wizytacji i rozmowach Rzecznika ze stu osobami przebywającymi w odwiedzonych jednostkach penitencjarnych okazało się, że część z nich prawdopodobnie nie powinna nigdy znaleźć się w więzieniu, część mogłaby odbywać karę nie w zwykłym reżimie, ale pod opieką specjalistów, korzystając z programów terapeutycznych w warunkach zapewniających bezpieczeństwo zarówno im, jak i współosadzonym i funkcjonariuszom. Osoby te trafiają do zakładów penitencjarnych, ponieważ informacje o niepełnosprawności umykają uwadze lub nie są uważane za istotne: policjanci ich nie odnotowują, prokuratorzy nie powołują biegłych w przypadku wątpliwości co do stanu zdrowia psychicznego danej osoby, sądy ignorują przesłanki świadczące o tym, że dana osoba może mieć kłopot z korzystaniem ze swoich praw (nie zapewnia się obligatoryjnego obrońcy), zapadają też wyroki nieuwzględniające możliwości skazanego do odbycia kary. Zdarza się, że kuratorzy wnioskują o umieszczenie w zakładzie karnym kogoś, kto nie zapłacił zasądzonej grzywny albo nie wykonał wskazanych w wyroku prac społecznie użytecznych, nie widząc tej osoby, a sąd nie sprawdza, czy taka osoba może w ogóle zasądzony wyrok wykonać. Funkcjonariusze Służby Więziennej nie przekazują ważnych informacji o osadzonym prokuratorom, sądom, sędziemu penitencjarnemu, nie wiedzą, jak 
reagować w takiej sytuacji, ponieważ nie są dostatecznie szkoleni. Sędziowie penitencjarni nie otrzymują sygnałów, które skłaniałyby do podjęcia działań w ramach ich kompetencji: spotkania $\mathrm{z}$ osadzonym, którego sytuacja wymaga interwencji, wydania zaleceń Służbie Więziennej, wystąpienia z urzędu o przerwę w odbywaniu kary (Więźniowie z niepetnosprawnością intelektualną... 2016).

Zdaniem prof. Janusza Heitzmana z Instytutu Psychiatrii i Neurologii w Warszawie prawo w Polsce jest dobre, ale źle stosowane.

Trzeba pamiętać, że na stan psychiczny człowieka mają wpływ uwarunkowania społeczne. Dlatego może nie wystarczyć jedno badanie psychiatryczne, a ocena ilorazu inteligencji nie przekłada się wprost na to, jakie paragrafy można zastosować. Jeśli do więzienia trafia osoba, która intelektualnie nie jest przystosowana do przemiany, to przecież cel naprawczy wymiaru sprawiedliwości nie zostanie osiągnięty (Więźniowie z niepetnosprawnościa intelektualną... 2016).

Po rozmowach Adama Bodnara ze skazanymi Biuro Rzecznika Praw Obywatelskich analizuje dokumenty pod kątem ewentualnej kasacji lub wniosku do sądu o wznowienie postępowania. Być może część z tych spraw zakwalifikuje się do tego, aby prezydent rozważył udzielenie aktu łaski niektórym ze skazanych.

\section{Kontrowersja w ramach prawa rodzinnego i opiekuńczego - prawo osób z niepełnosprawnością intelektualną lub chorobą psychiczną do małżeństwa}

Ową tytułową kontrowersję w polskich prawodawstwie stanowi artykuł 12 kodeksu rodzinnego i opiekuńczego (ustawa z dnia 25 lutego 1964 r. - Kodeks rodzinny i opiekuńczy, tekst jedn.: Dz. U. z 2017 r., poz. 682, ze zm.), zgodnie z którym: „Nie może zawrzeć małżeństwa osoba dotknięta chorobą psychiczną albo niedorozwojem umysłowym. Jeżeli jednak stan zdrowia albo umysłu takiej osoby nie zagraża małżeństwu ani zdrowiu przyszłego potomstwa i jeżeli osoba ta nie została ubezwłasnowolniona całkowicie, sąd może jej zezwolić na zawarcie małżeństwa”.

W listopadzie 2016 roku zakończyła się w Trybunale Konstytucyjnym sprawa, którą wniósł Rzecznik Praw Obywatelskich. Inspiracją było konkretne zdarzenie: urzędnik stanu cywilnego odmówił kobiecie z porażeniem mózgowym udzielenia ślubu, ponieważ miała ona problemy $\mathrm{z}$ wypowiadaniem się (była pełnosprawna intelektualnie). Na rozprawie przed Trybunałem przedstawicielka Rzecznika Praw Obywatelskich argumentowała, że owy przepis jest dyskryminujący, powodujący poczucie poniżenia i upokorzenia, narusza godność osoby oraz prawo do życia rodzinnego. $\mathrm{W}$ jej ocenie u podstaw tego artykułu leży motywacja eugeniczna: utrudnienie prokreacji osobom niepełnosprawnym intelektualnie. Jednak z naukowego punktu widzenia choroba psychiczna czy niepełnosprawność nie musi być 
dziedziczona. Nowoczesne leki pozwalają z kolei na kontrolowanie choroby psychicznej w taki sposób, że chory często normalnie funkcjonuje w środowisku rodzinnym i społecznym. Przedstawicielka Rzecznika Praw Obywatelskich podkreślała także, że małżeństwo korzystnie wpływa na chorego: „Przepis pochodzi z czasów, gdy uważano, że chorych psychicznie należy izolować od społeczeństwa. Dziśs wiemy, że należy ich właśnie włączać. Poza tym brak małżeństwa nie udaremnia prokreacji. Z badań aktowych wynika, że większość osób, które starały się o zgodę sądu na małżeństwo, albo miała już dzieci, albo ich właśnie oczekiwała" (Siedlecka 2016). Z owej relacji jasno wynika, że względny zakaz małżeństwa dla tych osób jest środkiem nieproporcjonalnym i nieprzydatnym.

Prawo do zawarcia małżeństwa przez osoby z niepełnosprawnością intelektualną na równych prawach $\mathrm{z}$ osobami pełnosprawnymi zawiera Konwencja ONZ o prawach osób niepełnosprawnych, sporządzona w Nowym Jorku dnia 13 grudnia 2006 r. (Dz. U. z 2012 r., poz. 1169). Polska ratyfikowała konwencję w 2012 roku, ale złożyła do niej zastrzeżenie właśnie w punkcie dotyczącym równości osób niepełnosprawnych intelektualnie w małżeństwie i innych prawach cywilnych. Dlatego Rzecznik Praw Obywatelskich nie mógł powołać się na konwencję w skardze do Trybunału. Za czasów rządów Platformy Obywatelskiej w Ministerstwie Sprawiedliwości trwały prace nad dostosowaniem polskich przepisów w tym punkcie do konwencji, ale ich nie zakończono. Obecnie, w związku z likwidacją działającej przy ministrze sprawiedliwości komisji kodyfikacyjnej prawa cywilnego, sprawa w ogóle się nie toczy.

Trybunał Konstytucyjny nie uznał za słusznych argumentów Rzecznika Praw Obywatelskich. Sędzia prawoznawca Andrzej Wróbel podkreślił, że polska konstytucja nie zawiera prawa do małżeństwa, a zawarte w niej (art. 47) prawo do życia rodzinnego należy czytać w kontekście artykułu 18, który ustanawia ochronę małżeństwa, rodziny i rodzicielstwa: „Konwencja o prawach osób niepełnosprawnych za najważniejszą wartość, w kontekście małżeństwa, uważa indywidualną wolność. Polskie prawo - ochronę małżeństwa, rodziny, rodzicielstwa i dobro dziecka" (Siedlecka 2016). Podkreślił także, że ograniczenie prawa osób z niepełnosprawnością intelektualną do małżeństwa zmierza właśnie do ochrony tych wartości. Trybunał nie zgodził się też, że przepis narusza zasadę poszanowania godności człowieka. Zdaniem Trybunału w tym przypadku można by mówić o naruszeniu godności rozumianej nie jako cecha konstruktywna każdego człowieka, ale o naruszeniu godności osobistej, a ta może być ograniczona, podobnie jak inne prawa i wolności człowieka, np. ze względu na ochronę praw i wolności innych osób. I tak jest właśnie zdaniem Trybunału w tym przypadku - w szczególności chodzi o zagwarantowanie bezpieczeństwa i dobra dzieci (Siedlecka 2016). 


\section{Literatura}

Andrzejuk R., 2004, Prawa człowieka podstawa prawa narodów do samostanowienia, Lublin: Towarzystwo Naukowe KUL.

Banaszczyk Z., 1997, Czyny niedozwolone [w:] idem, Kodeks cywilny. Komentarz, t. 1, red. K. Pietrzykowski, Warszawa: C.H. Beck.

Cytowska B., 2012, Trudne drogi adaptacji. Watki emancypacyjne w analizie sytuacji dorosłych osób z niepełnosprawnościa intelektualna we współczesnym społeczeństwie polskim, Kraków: Oficyna Wydawnicza „Impuls”.

Dąbrowski S., Pietrzykowski J., 1997, Ustawa o ochronie zdrowia psychicznego - komentarz, Warszawa: Instytut Psychiatrii i Neurologii.

Filar M., 2006, Wyłączenie odpowiedzialności karnej [w:] Kodeks karny. Komentarz, red. O. Górniok et al., Warszawa: LexisNexis, wyd. 2.

Gałecki P., Eichstaedt K., Bobińska K., 2012, Aspekty i orzecznictwo u osób z niepetnosprawnościq intelektualna w polskim ustawodawstwie [w:] Niepełnosprawność intelektualna - etiopatogeneza, epidemiologia, diagnoza, terapia, red. K. Bobińska, T. Pietras, P. Gałecki, Wrocław: Continuo.

Gromek K., 2001, Komentarz do ustawy o postępowaniu w sprawach nieletnich, Warszawa: Wydawnictwo Prawnicze.

Hajdukiewicz D., 2004, Opiniowanie sadowo-psychiatryczne w sprawach cywilnych, Warszawa: Instytut Psychologii i Neurologii.

Hajdukiewicz D., 2007, Podstawy prawne opiniowania sądowo-psychiatrycznego w postepowaniu karnym, w sprawach o wykroczenia oraz $w$ sprawach nieletnich, Warszawa: Instytut Psychiatrii i Neurologii.

Łuniewski W., 1950, Zarys psychiatrii sądowej. Część ogólna, Warszawa: Państwowy Zakład Wydawnictw Lekarskich.

Pazdan M., 1997, Zdolność prawna i zdolność do czynności prawnych [w:] Kodeks cywilny. Komentarz, t. 1, red. K. Pietrzykowski, Warszawa: C.H. Beck.

Piechowiak M, 1999, Filozofia praw człowieka: prawa człowieka w świetle ich międzynarodowej ochrony, Lublin: Towarzystwo Naukowe Katolickiego Uniwersytetu Lubelskiego.

Przybysz J., 2003, Psychiatria sądowa. Opiniowanie w procesie karnym. Podręcznik dla lekarzy i prawników, Toruń: Fundacja Tumult.

Sokołowski T., 2004, Międzynarodowa ochrona praw człowieka: zarys, Warszawa: WSP TWP.

Szczupał B., 2009, Godność osoby z niepełnosprawnością. Studium teoretyczno-empiryczne poczucia godności młodzieży z dysfunkcja narządu ruchu, Kraków: Wydawnictwo Naukowe Akapit.

Uszkiewiczowa L., 1973, Opinia biegłego psychiatry w postępowaniu cywilnym [w:] Opinia biegłego z zakresu psychiatrii, red. L. Uszkiewiczowa, Warszawa: Wydawnictwo Prawnicze.

Więźniowie z niepełnosprawnością intelektualna lub psychiczną. RPO opowiada o wynikach badań $w$ więzieniach i o tym, co zrobi, by pomóc osobom, które nigdy nie powinny byly trafić do więzienia, 2016, https://www.rpo.gov.pl/pl/content/wiezniowie-o-umyslowosci-dzieci-chorzy-psychicznie-rpo-opowiada-o-wynikach-badan-w-wiezieniach [dostęp: 24.07.2017]. 
Wstępne wyniki z Narodowego Spisu Powszechnego 2011 w zakresie populacji osób niepełnosprawnych, 2011, http://niepelnosprawni.gov.pl/container/niepelnosprawnosc-w-liczbach/dane-demograficzne/wstepne-wyniki-z-narodowego-spisu-powszechnego-2011w-zakresie-populacji-osob-niepelnosprawnych.pdf [dostęp: 25.07.2017].

Zyss T. (red.), 2009, Orzecznictwo rentowe ze szczególnym uwzględnieniem psychiatrii, Kraków: Wydawnictwo Medyczne, wyd. 2.

\section{Dokumenty}

Deklaracja Praw Osób Upośledzonych Umysłowo - Rezolucja 2856 (XXVI)

Europejska Karta Społeczna sporządzona w Turynie dnia 18 października 1961 r. (Dz. U. z 2011 r. Nr 168, poz. 1007)

Europejska Karta Społeczna (zrewidowana) z dnia 3 maja 1996 r.

Konstytucja Rzeczypospolitej Polskiej z dnia 2 kwietnia 1997 r. (Dz. U. z 1997 r. Nr 78, poz. 483, ze zm.)

Konwencja ONZ o prawach osób niepełnosprawnych, sporządzona w Nowym Jorku dnia 13 grudnia 2006 r. (Dz. U. z 2012 r., poz. 1169)

Konwencja o prawach dziecka przyjęta przez Zgromadzenie Ogólne Narodów Zjednoczonych dnia 20 listopada z 1989 r. (Dz. U. z 1991 r. Nr 120, poz. 526)

Obwieszczenie Marszałka Sejmu Rzeczypospolitej Polskiej z dnia 5 kwietnia 2017 r. w sprawie ogłoszenia jednolitego tekstu ustawy o ochronie zdrowia psychicznego (Dz. U., poz. 882)

Plan działań Rady Europy w celu promocji praw i pełnego uczestnictwa osób niepełnosprawnych w społeczeństwie: podnoszenie jakości życia osób niepełnosprawnych w Europie 2006-2015.

Rozporządzenie Rady Ministrów z dnia 15 maja 1989 r. w sprawie uprawnień do wcześniejszej emerytury pracowników opiekujących się dziećmi wymagającymi stałej opieki (Dz. U. Nr 28, poz. 149)

Uchwała Sejmu Rzeczypospolitej Polskiej z dnia 1 sierpnia 1997 r. - Karta Praw Osób Niepełnosprawnych (M.P. Nr 50, poz. 475)

Ustawa z dnia 25 lutego 1964 r. - Kodeks rodzinny i opiekuńczy (tekst jedn.: Dz. U. z 2017 r., poz. 682, ze zm.)

Ustawa z dnia 23 kwietnia 1964 r. - Kodeks cywilny (tekst jedn.: Dz. U. z 2017 r., poz. 459 ze zm.)

Ustawa z dnia 17 listopada 1964 r. - Kodeks postępowania cywilnego (tekst jedn.: Dz. U. z 2016 r., poz. 1822, ze zm.)

Ustawa z dnia 26 października 1982 r. o postępowaniu w sprawach nieletnich (tekst jedn.: Dz. U. z 2016 r., poz. 1654, ze zm.)

Ustawa z dnia 19 sierpnia 1994 r. o ochronie zdrowia psychicznego (tekst jedn.: Dz. U. z 2017 r., poz. 882, ze zm.)

Ustawa z dnia 6 czerwca 1997 r. - Kodeks karny (tekst jedn.: Dz. U. z 2016 r., poz. 1137, ze zm.)

Ustawa z dnia 6 czerwca 1997 r. - Kodeks postępowania karnego (tekst jedn.: Dz. U. z 2017 r., poz. 1904, ze zm.) 
Ustawa z dnia 27 sierpnia 1997 r. o rehabilitacji zawodowej i społecznej oraz zatrudnianiu osób niepełnosprawnych (tekst jedn.: Dz. U. z 2016 r., poz. 2046, ze zm.)

Ustawa z dnia 17 grudnia 1998 r. o emeryturach i rentach z Funduszu Ubezpieczeń Społecznych (tekst jedn.: Dz. U. z 2017 r., poz. 1383, ze zm.)

Ustawa z dnia 3 grudnia 2010 r. o wdrożeniu niektórych przepisów Unii Europejskiej w zakresie równego traktowania (Dz. U. z 2016 r., poz. 1219)

Wyrok SN z dnia 25 lutego 2009 r. (II KK 316/08)

\begin{abstract}
Abstrakt
Z wstępnych wyników Narodowego Spisu Powszechnego z 2011 roku w zakresie populacji osób niepełnosprawnych wynika, że liczba osób kwalifikujących się do zaliczenia ich do owej zbiorowości wynosiła 4697 500, co stanowiło 12,2\% ludności kraju. Celem artykułu jest analiza oraz omówienie głównych założeń zawartych w wybranych artykułach polskiego oraz europejskiego prawodawstwa ze szczególnym zwróceniem uwagi na kwestie, które bezpośrednio dotyczą osób z niepełnosprawnością oraz osób z zaburzeniami psychicznymi.
\end{abstract}

\title{
Słowa kluczowe
}

niepełnosprawność, zaburzenia psychiczne, ubezwłasnowolnienie, prawo polskie, prawo europejskie

\section{Summary}

The rights of people with intellectual disability in the eyes of European and Polish legislation

Preliminary results of The National General Census from 2011 about persons with disability population shows that number of people qualifying for classification them to this communities amount -4697500 , it constituted $12,2 \%$ of population of a country. The aim of this article is analysis and disscusion of main assumptions contained in selected articles of Polish and European legistation with particular drawing attention to issues, which is directy concerned by persons with disability and persons with mental distress.

\section{Keywords}

disability, mental distress, interdiction, Polish law, European law 